\title{
An experimental investigation of a micro-tubular SOFC membrane-separated liquid desiccant dehumidification and cooling tri-generation system
}

\author{
Mark Worall* \\ Architecture, Energy and Environment Research Group, the University of Nottingham, Nottingham, NG7 2RD \\ T: +44(0) 115 8467673, email: mark.worall@nottingham.ac.uk \\ *corresponding author
}

Theo EImer

Architecture, Energy and Environment Research Group, the University of Nottingham, Nottingham, NG7 2RD

Email: theo.elmer@nottingham.ac.uk

\section{Saffa Riffat}

Architecture, Energy and Environment Research Group, the University of Nottingham, Nottingham, NG7 2RD

Email: saffa.riffat@nottingham.ac.uk

\section{Shenyi Wu}

Fluids and Thermal Engineering Research Group, the University of Nottingham, Nottingham, NG7 2RD

Email: shenyi.wu@nottingham.ac.uk

\section{Shangfeng Du}

School of Chemical Engineering, the University of Birmingham, Birmingham, B15 2TT

Email: S.Du@bham.ac.uk

\begin{abstract}
This paper reports the results of experimental work carried out on a micro-tubular solid oxide fuel cell tri-generation system that uses the waste heat from the fuel cell for dehumidification and cooling though the integration of an open cycle liquid desiccant dehumidification and cooling system. The experimental results demonstrate regeneration of the potassium formate solution using the thermal output from the SOFC in the first of its kind tri-generation system. Optimisation has shown that a $2.2 \mathrm{~L} \cdot \mathrm{min}^{-1}$ regenerator desiccant volumetric flow facilitates best performance. When integrated with the micro-SOFC, the open cycle desiccant system demonstrates a COP of approaching 0.7 , an encouraging value for a waste heat driven cooling system of this capacity. A tri-generation performance analysis is presented which serves to demonstrate the novel system operating in a building. The system achieved an electrical efficiency of $11 \%$ and regeneration efficiency of approximately $37 \%$. The electrical efficiency is lower than that predicted by the company supplying the micro-tubular SOFC, because the unit suffered sulphur poisoning during preliminary tests. The electrical power output decreased from $250 \mathrm{~W}$ to $150 \mathrm{~W}$, which reduced the electrical efficiency from around $18 \%$ to $11 \%$ and the overall efficiency from approximately $45 \%$ to just over $37 \%$. Low temperature $\left(33-36^{\circ} \mathrm{C}\right)$ regeneration was demonstrated.
\end{abstract}




\section{Highlights}

- An instantaneous regenerator efficiency of $23 \%$ and trigeneration efficiency of $50 \%$ was achieved.

- Over a cycle, a regenerator efficiency of $23 \%$ and a trigeneration efficiency of $37 \%$ was achieved

- An instantaneous COP of approximately 0.7 and an overall system COP of 0.4 was achieved

- Regeneration was achieved at relatively low temperatures ranging from $33-36^{\circ} \mathrm{C}$.

Keywords: fuel cell, SOFC, microtubular, tri-generation, desiccant, dehumidification 


\section{Introduction}

One of the more promising possibilities for clean small scale electrical power generation is solid oxide fuel cell (SOFC) technology, which can generate electricity through an electrochemical process that brings together hydrogen from the fuel and oxygen from the air ( Boyd, 2008). The only by-products are waste heat, water vapour and carbon dioxide. Chemical to electrical energy conversion efficiencies can be over $50 \%$ compared to $30-40 \%$ in combustion processes. Technical assessments have demonstrated that if combined heat and power (CHP) technology is used with SOFC, the total system efficiency of as high as $90 \%$ can be achieved.

Liquid desiccant systems in the heating, ventilation, and air conditioning (HVAC) applications, are used primarily where simultaneous maintenance of temperature and humidity control is an important benefit to the user. This technology is often used in tri-generation systems, where the desiccant system is driven by the heat by-product. If the waste heat from SOFCs is used to drive the desiccant unit, then a trigeneration system will result, supplying not only the power and heat as the conventional CHP technology to the building, but also cooling and humidity control.

This paper will describe the development, design, construction and testing of a micro-tubular SOFC trigeneration system for low carbon buildings.

\subsection{Fuel cells}

Fuel cells have recently been identified as a key technological option for improving both building energy efficiency and reducing emissions en-route to a zero carbon built environment (Hawkes, et al, 2009, Kazempoor, et al, 2011). Fuel cells are not heat engines, and thus their efficiencies are not limited by the Carnot efficiency. Fuel cells consist of an anode, a cathode and an electrolyte, and when hydrogen is fed to the anode and oxygen is fed to the cathode, the reaction across a solid electrolyte membrane produces electrical energy (Crabtree and Dresselhaus, 2008). By combining hydrogen and oxygen in electrochemical reaction, as shown in figure 1.1, fuel cells have the potential to produce highly efficient electrical power with little or no emission of environmentally damaging pollutants, such as $\mathrm{CO}_{2}$.

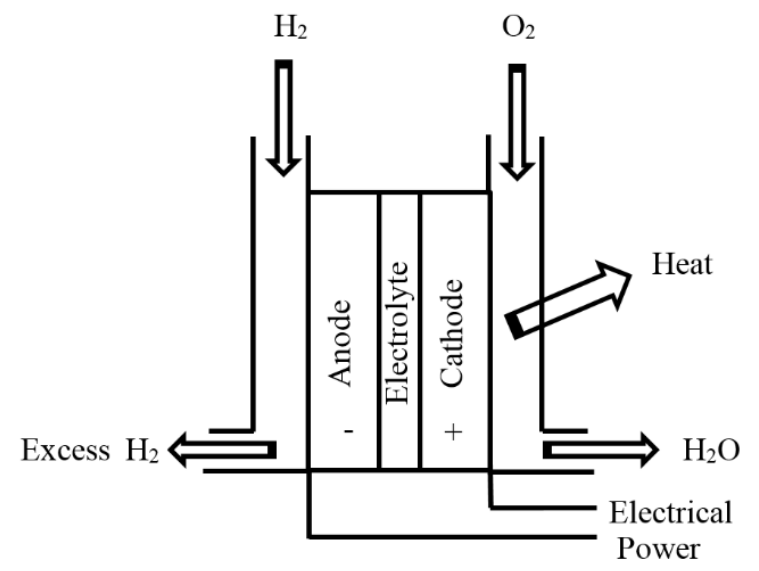

Figure 1.1. Fuel cell concept

The exothermic nature of the electrochemical reactions makes fuel cells ideal candidates for CHP and tri-generation system applications. Solid oxide fuel cells (SOFC) are being developed as viable power generators with the ability to provide process heat as a by-product and so this review will focus on these SOFC developments rather than the whole fuel cell market. SOFCs come in many forms, but the most common are planar type units. The planar fuel cell consists of many membranes connected in parallel and series, which are flat and are arranged in stacks. More recently, micro-tubular fuel cells have been 
developed. In the early 1990s the micro-tubular type SOFC was invented, according to Howe, et al, (2011), which feeds hydrogen and oxygen to opposite sides of a hollow extruded tube. The structure of this design is shown in Figure 1.2a.

a:

(a)
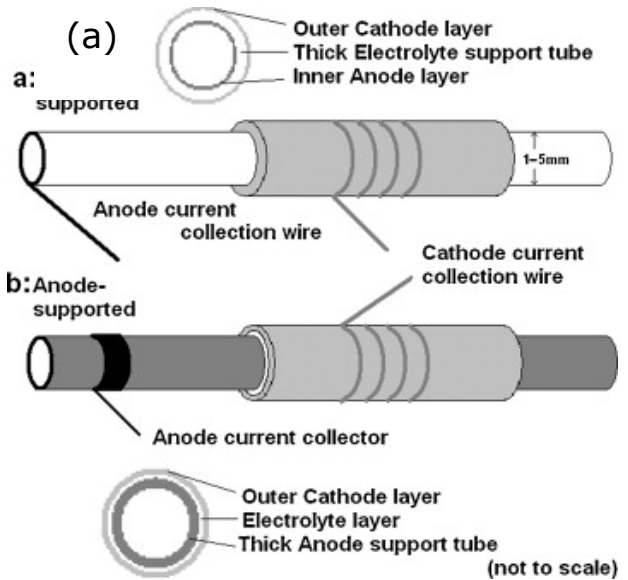

(b)

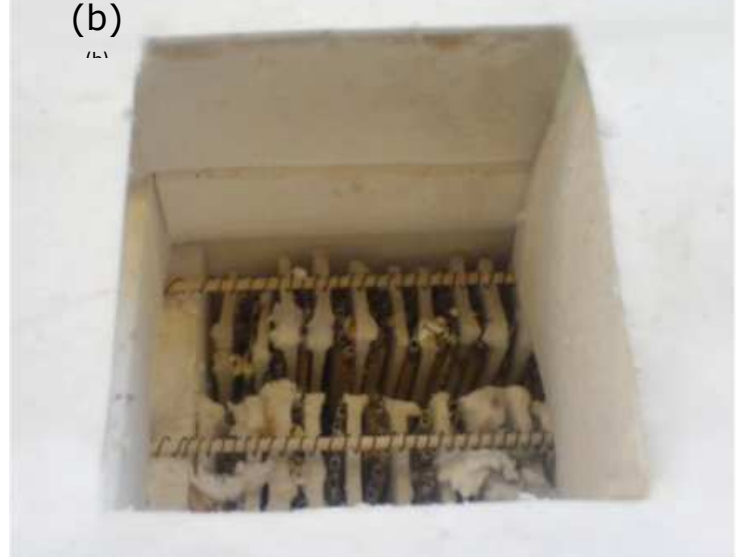

Figure 1.2. (a) basic SOFC micro-tubular designs (Howe, et al, 2011), and (b) a 100 tube SOFC stack

Although micro-SOFCs show desirable operational characteristics such as high volumetric power density, good endurance against thermal cycling, and rapid start-up, important performance parameters, such as fuel utilisation and electrical efficiency are comparatively low. By more fully utilising the energy available, micro-SOFCs could be applicable in small stationary applications that require heat, coolth and back-up power. A micro-SOFC tri-generation system integrating open cycle desiccant dehumidification and cooling could provide valuable functionality to the system as well as enhancing the efficiency of the system.

\subsection{Fibre membrane separated dehumidification and cooling}

Air conditioning of buildings involves both sensible cooling and latent cooling. Conventional systems chill the air to below its dew point to condense water vapour and remove it from the supply air and then use heating systems to increase the temperature to a suitable value. Desiccants can absorb the latent heat through direct contact with the humid air, thus leaving chillers to sensibly cool supply air to a comfortable temperature and reducing energy consumption and improving process efficiency. An open cycle liquid desiccant dehumidification system transfers moisture because of a difference between the water vapour pressure at the surface and that of the surrounding air (ASHRAE, 1997). A recent study by Kozubal, et al (2011) of a desiccant enhanced evaporative air conditioning system demonstrated a $30-90 \%$ reduction in energy demand compared to an equivalent vapour compression system.

Figure 1.3 illustrates how a typical liquid desiccant cycle works. At (1), the solution is at a certain concentration depending on its vapour pressure, moisture content and temperature. As it absorbs moisture from the air, the moisture content, temperature and vapour pressure increase to (2). As vapour pressure increases, its ability to absorb moisture decreases until the desiccant vapour pressure reaches equilibrium with the air. In order to remove moisture, regeneration is necessary. At (3), the moisture is desorbed from the solution, causing an increase in vapour pressure and vapour pressure, but a decrease in moisture content. This is usually achieved be applying heat to the solution to desorb some of the moisture. The solution now has low moisture content, but a high temperature and vapour pressure. In order to be able to carry out dehumidification, the solution is cooled back to (1). This can be achieved by recovering some of the heat ( 1 to 2 and 2 to 3 ) and by external cooling processes such as evaporative cooling. The open cycle desiccant system is simple, cyclic, has comparatively high performance and can regenerate at relatively low temperatures $\left(45-65^{\circ} \mathrm{C}\right)$. It is ideally suited to low temperature solid 
oxide fuel cell applications such as buildings, in which low grade heat is required for heating in winter and cooling in summer.

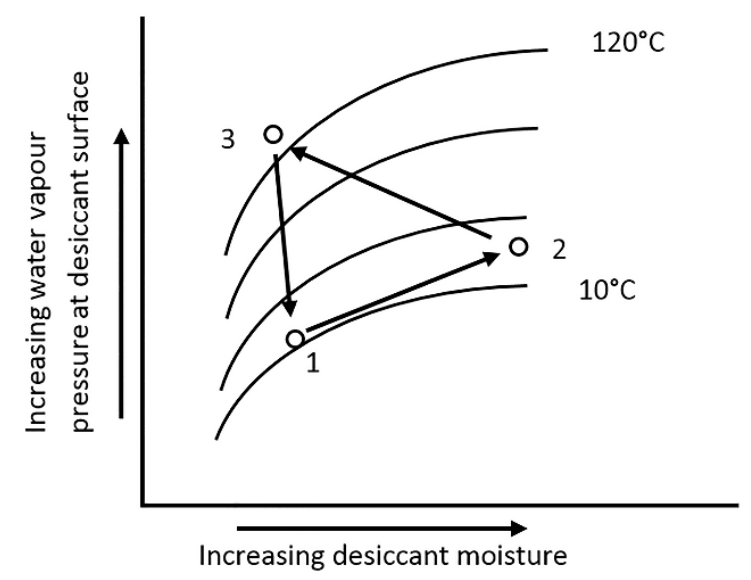

Figure 1.3. Illustration of the change in vapour pressure with temperature and moisture content (ASHRAE, 1997)

Most liquid desiccant systems employ organic salt-based solutions such as lithium chloride or calcium chloride, which have very low vapour pressures and so readily absorb moisture, but most are highly corrosive, many are harmful to health and some are toxic. In direct contact liquid dehumidifiers, desiccant liquid carry-over can be a major disadvantage as droplets can come into contact with people and incompatible materials, thus posing a potential health hazard and causing corrosion issues. In order to take advantage of the excellent absorption performance, but eliminate the disadvantages, fibre membrane heat/mass exchangers have been developed. In previous publications (Elmer et al, 2016) we have disseminated state of the art, modelling and simulations, and experimental work on this subject and concluded that potassium formate was the most appropriate liquid desiccant for use with this system.

Figure 1.4 shows a diagram of the fibre membrane mass/heat exchanger. Fibre membranes form channels that separate the humid air and liquid desiccant solution.

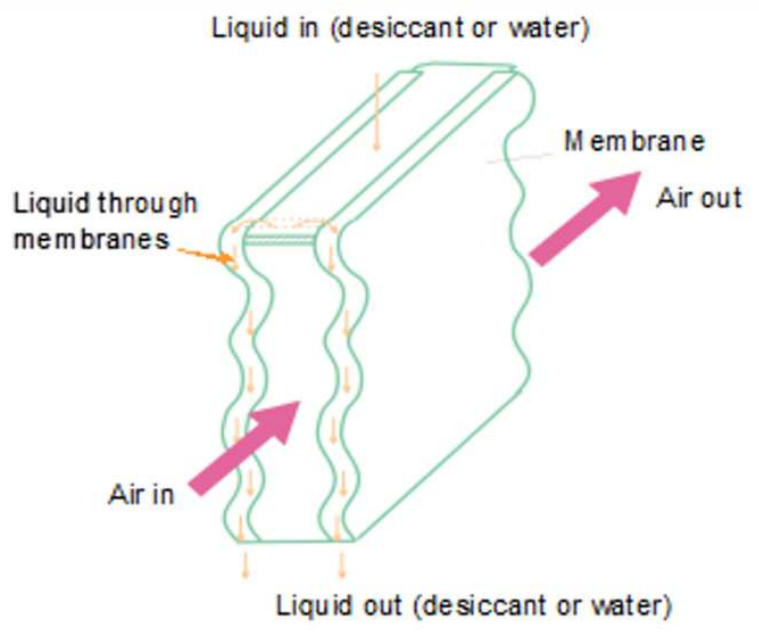

Figure 1.4. Sketch of a fibre membrane heat/mass exchanger 
The desiccant solution is introduced at the top of the membrane channels and flows vertically downward, whilst air is introduced in cross-flow through adjacent channels. The fibre membranes are constructed so that the pore sizes are small enough to prevent liquid desiccant to pass through, but large enough to allow moisture to pass through (Liu, et al 2009).

\section{Performance parameters}

The object of the experimental work is to investigate the performance of the novel micro-tubular SOFC tri-generation system under realistic operating conditions. In order to understand the system performance, important performance parameters are described below.

The electrical efficiency of the system is defined as the ratio of the electricity generated to the total chemical and work input

$\eta_{\text {elec }}=W_{\mathrm{e}} /\left(Q_{\text {fuel }}+W_{\text {e-out }}\right)$

Where $W_{\mathrm{e}}(\mathrm{W})$ is the electrical power output from the fuel cell, $Q_{\text {fuel }}(\mathrm{W})$ is the chemical input from the fuel and $W_{\text {e-out }}(\mathrm{W})$ is the electrical power consumed by the fuel cell and dehumidification system (pumps, fans, switches, etc).

The instantaneous tri-generation system efficiency is the ratio of the total useful heat and work output to the total chemical and electrical power input.

$\eta_{\text {tri }}=\left(Q_{\text {regen }}+W_{\mathrm{e}}\right) /\left(Q_{\text {fuel }}+W_{\text {e-out }}\right)$

Where $Q_{\text {regen }}(\mathrm{W})$ is the heat recovered from the exhaust gases and available for use in the system.

The purpose of the regeneration process is to remove water from the solution in order to increase its concentration and enable it to be used for dehumidification, therefore we define the regeneration efficiency as;

$\eta_{\text {regen }}=\left(Q_{\text {lat }}+W_{\mathrm{e}}\right) /\left(Q_{\text {fuel }}+W_{\mathrm{e}-\mathrm{out}}\right)$

Where $Q_{\text {lat }}(\mathrm{W})$ is the latent heat transferred in removing the moisture from the solution.

The instantaneous coefficient of performance (COP) of the system is defined as the ratio of total cooling provided to the total regenerator heat and work input.

$\mathrm{COP}_{\text {tri }}=Q_{\text {cool }} /\left(Q_{\text {regen }}+W_{\text {e-out }}\right)$

Absorption and desorption are driven by vapour pressure differences between water vapour in the air and the vapour pressure of the solution above the surface of a desiccant. Absolute humidity is the ratio of the mass of water vapour in air to the mass of dry air ( $\mathrm{kg}$ water vapour $/ \mathrm{kg}$ dry air) and is a function of temperature and vapour pressure in the case of humid air, and temperature and concentration in the case of a desiccant solution. The effectiveness of the membrane heat/mass exchanger will be assessed by defining the regeneration effectiveness, as the ratio of the absolute humidity difference between air inlet $\omega_{i n}$, and outlet, $\omega_{\text {out }}$, to the difference between the solution equilibrium absolute humidity (at the solution temperature and concentration) $\omega_{e q}$ at the solution surface and the inlet absolute humidity.

$\varepsilon_{\text {regen }}=\frac{\left(\omega_{\text {out }}-\omega_{\text {in }}\right)}{\left(\omega_{\text {eq }}-\omega_{\text {in }}\right)}$

To determine the absolute humidity at the solution surface it is necessary to determine the vapour pressure of the solution above the surface. Appendix A describes the equations and correlations used to determine the vapour pressure of the desiccant solution of Potassium Formate (HKOOK) and water.

\section{Description of micro-tubular SOFC tri-generation test rig}


This paper is mainly concerned with disseminating knowledge about the development and testing of a micro-tubular SOFC tri-generation system, but initially will also describe bench tests carried out by one of our consortium partners, the University of Birmingham (UoB), who investigated the operation of the micro-tubular SOFC alone.

\subsection{Micro-tubular SOFC bench tests}

Figure 3.1a shows a photograph of the micro-tubular SOFC bench test rig. It consists of the microtubular fuel cell (size of a desk-top computer), a propane cylinder, a propane regulator, a sulphur trap, a battery pack, an electrical load (12v dc heater elements and lamps) and measuring instruments.

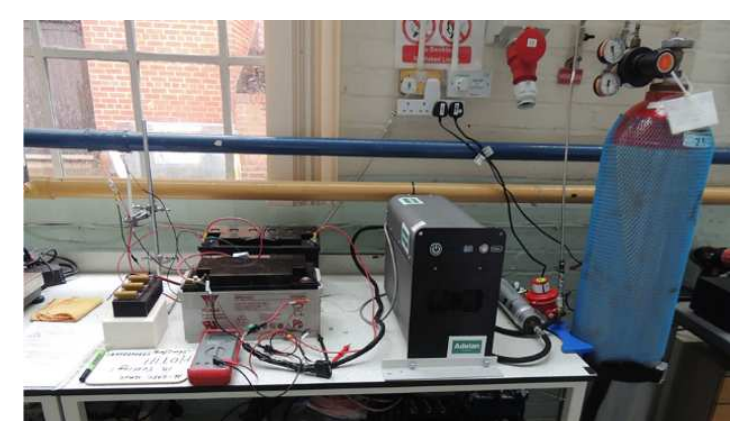

(a)

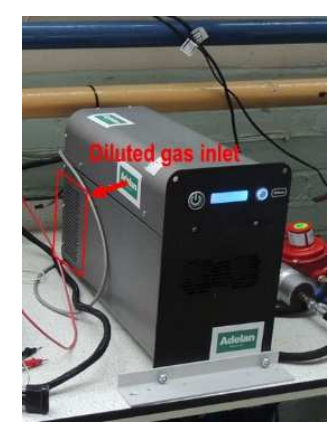

(b)

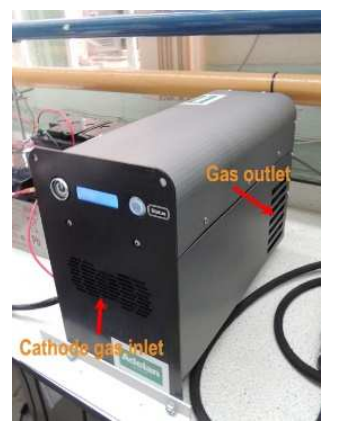

(c)

Figure 3.1. Photograph of the micro-tubular SOFC bench test rig

Figures 3.1(b) and 3.1(c) show the fuel cell with indications of air inlet and exhaust outlet points.

\subsection{Micro-tubular SOFC tri-generation test rig construction}

Figure 3.2 presents a schematic diagram of the experimental micro-SOFC liquid desiccant trigeneration system. The three main sections (1) SOFC power generation system, (2) SOFC waste heat recovery (WHR) circuit and (3) liquid desiccant system. 


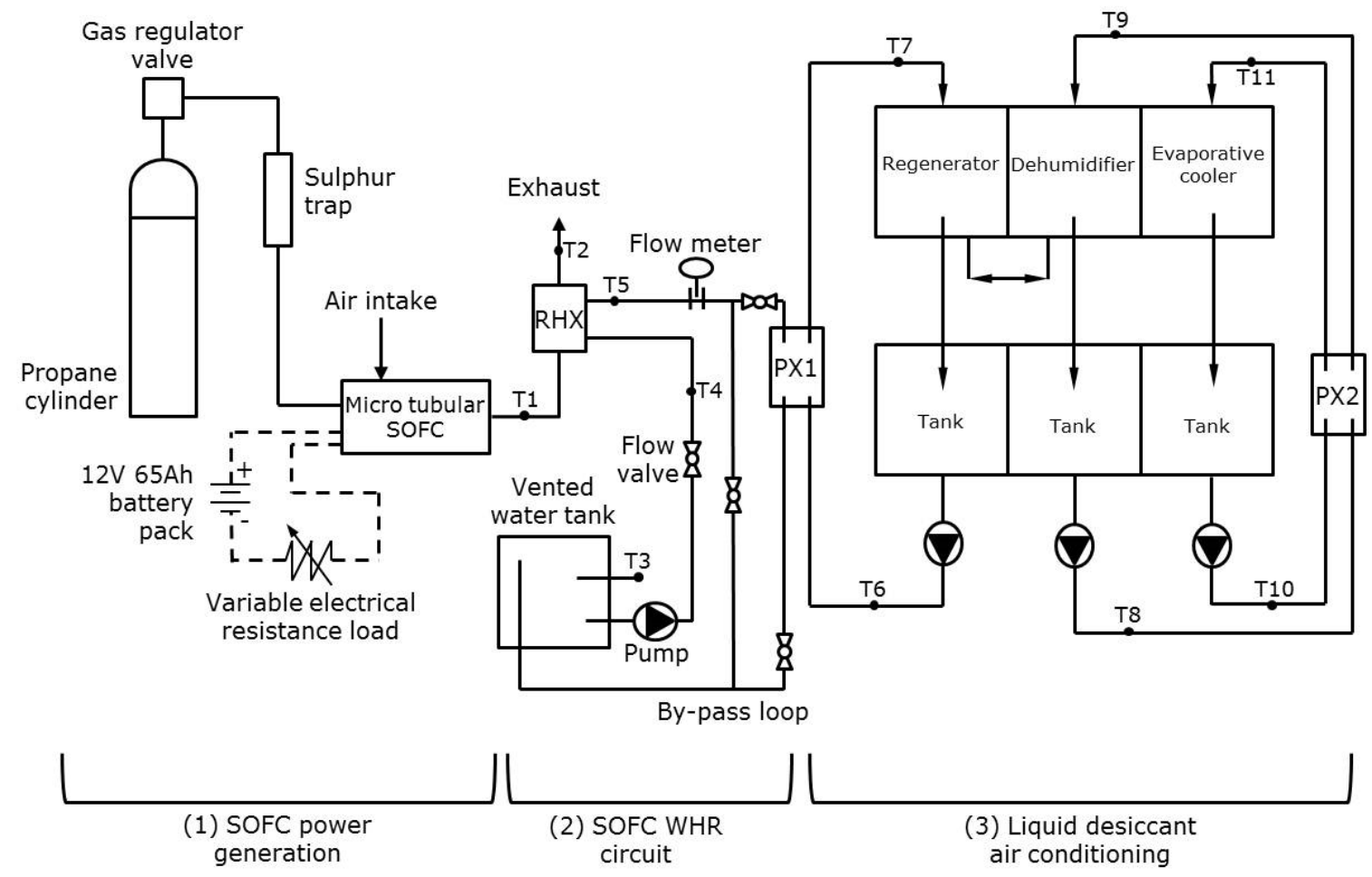

Figure 3.2. Diagram of the micro-SOFC dehumidification and cooling rig

Section 1 consisted of a micro-tubular SOFC of $250 \mathrm{~W}$ of electrical output and 1000W of heat output, a propane cylinder, a regulator, a sulphur trap, an electrical load provided by an array of 50W DC lamps, and a $12 \mathrm{~V}$ DC $65 \mathrm{Ah}$ battery pack. Section 2 consisted of the exhaust heat recuperator (RHX), a water circuit, a pump, a flow control valve and a flow meter. The liquid desiccant air conditioning unit (3) consisted of a dehumidifier, a regenerator and an evaporative cooler.

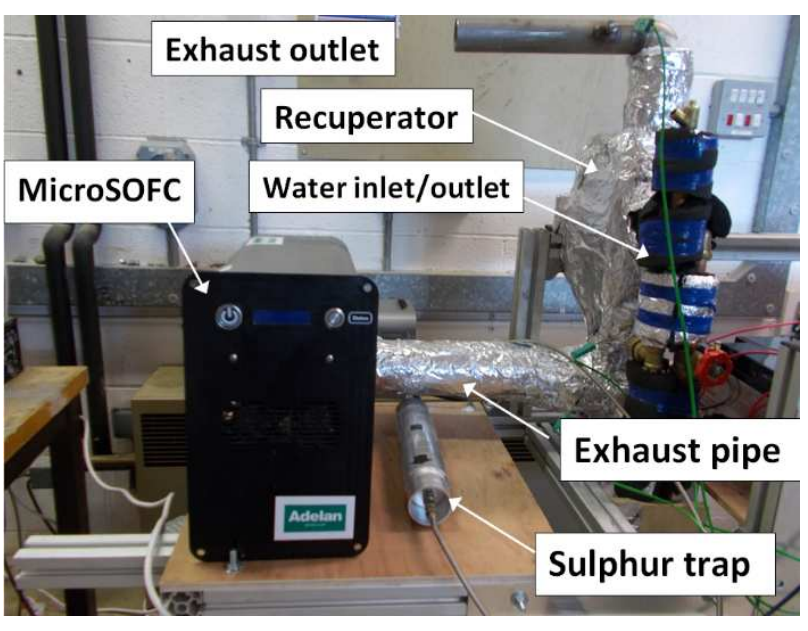

(a)

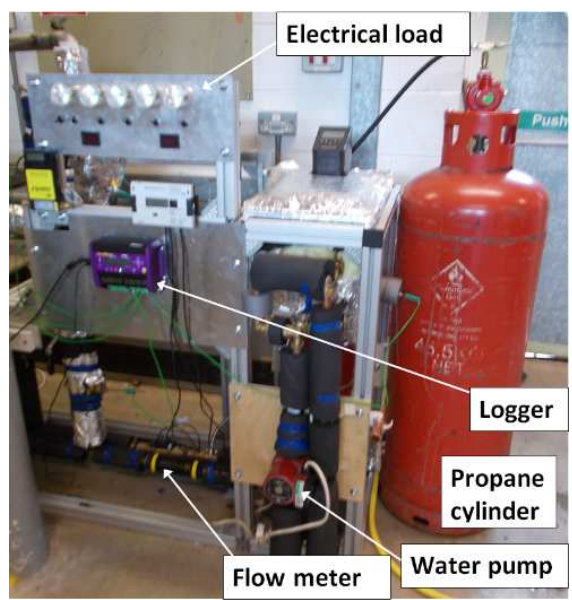

(b)

Figure 3.3. Photograph of (a) the SOFC power generation and (b) WHR circuit 


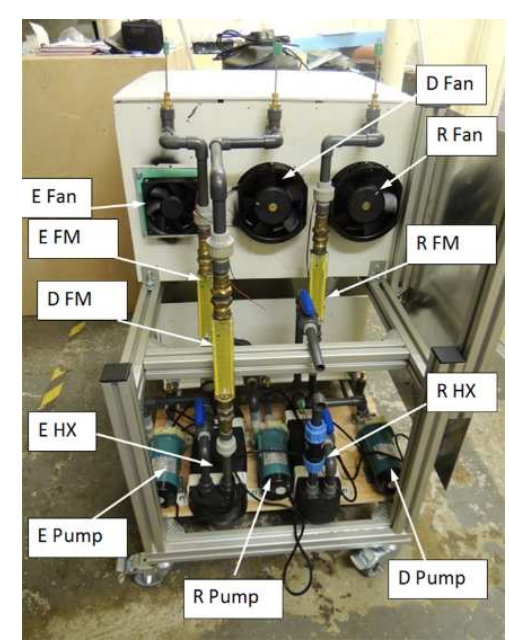

(a)

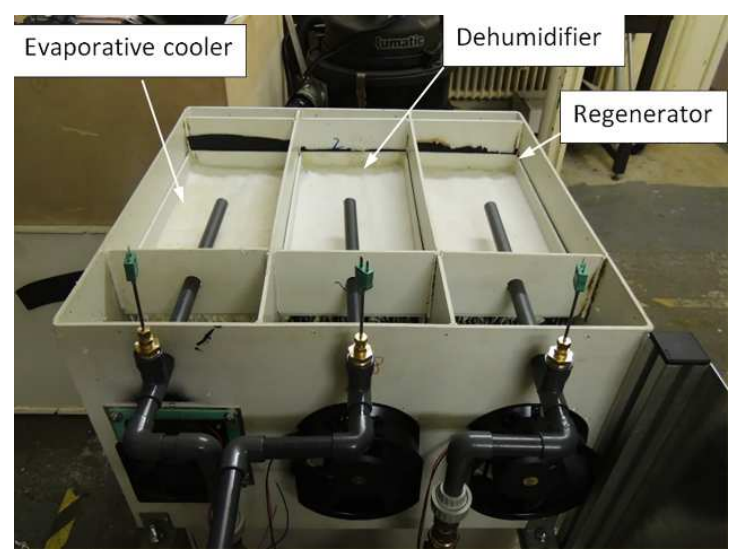

(b)

Figure 3.4. Photograph of (a) desiccant unit (b) membrane section

Figure 3.3(a) shows the micro-tubular SOFC, the exhaust pipe, the recuperator, the sulphur trap and the exhaust outlet. Figure 3.3(b) shows the propane cylinder, the regulator, the electrical load, the datalogger, the pump and flow meter. Figure 3.4(a) and 3.4(b) shows the dehumidifier, which consists of three distinct sub-cycles, a dehumidifier, a regenerator and an evaporative cooler. In each circuit, a magnetically driven centrifugal pump delivers liquid from a tank situated at the bottom of the rig to the membrane mass/heat exchangers at the top of the rig. In the dehumidification circuit, a pump (D Pump) delivers strong desiccant solution from a tank at the base of the unit to the membrane mass/heat exchangers at the top of the unit (Dehumidifier). The desiccant flows through a plate heat exchanger (E HX) which transfers heat from the desiccant system to the evaporative cooling system. An axial flow fan (D Fan) directs air through the dehumidifier mass/heat exchanger. A pump (R pump) delivers dilute solution to the top of the regenerator via a plate heat exchanger (R HX) which transfers the heat from the fuel cell to the solution. An axial fan (R Fan) directs air through the regenerator heat/mass exchanger. The unit was placed in an environmental chamber where temperature and humidity could be controlled. Worall et al (2012) described modelling and analysis, which concluded that potassium formate $\left(\mathrm{CHKO}_{2}\right)$ was the most suitable desiccant because of its good regeneration capacity at the low temperatures and its reduced corrosion risks compared to other liquid desiccant solutions. Elmer et al (2015a), Elmer (2015b) and Elmer et al (2016) described the development and testing of the desiccant unit. Table 3.1 lists the measurement devices along with their ranges and accuracies.

Table 3.1 Instrumentation equipment and associated accuracy

\begin{tabular}{llll}
\hline $\begin{array}{l}\text { Measurement } \\
\text { device }\end{array}$ & Measurement subject & $\begin{array}{l}\text { Measurement } \\
\text { Range }\end{array}$ & Accuracy (of the reading) \\
\hline $\begin{array}{l}\text { HMP110 relative } \\
\text { humidity and } \\
\text { temperature probe }\end{array}$ & $\begin{array}{l}\text { Air relative humidity } \\
\text { and temperature }\end{array}$ & $R H_{\mathrm{a}}= \pm 1.7 \%$ \\
$\begin{array}{l}\mathrm{RS} \text { AM4204 hot } \\
\text { wire anemometer }\end{array}$ & Air velocity & 0 to $20 \mathrm{~m} / \mathrm{s}$ & $u_{\text {air }}= \pm 0.2^{\circ} \mathrm{C}$ \\
$\begin{array}{l}\text { Type-K } \\
\text { thermocouple probe }\end{array}$ & $\begin{array}{l}\text { Desiccant solution and } \\
\text { water temperature }\end{array}$ & 0 to $1100^{\circ} \mathrm{C}$ & $T_{\text {des }} / T_{\mathrm{w}}= \pm 0.5^{\circ} \mathrm{C}$ \\
$\begin{array}{l}\text { Parker Liquid Flow } \\
\text { Indicator }\end{array}$ & $\begin{array}{l}\text { Desiccant solution and } \\
\text { water volumetric flow }\end{array}$ & 1.5 to $10 \mathrm{~L} / \mathrm{min}$ & $v_{\text {des }} / v_{\mathrm{w}}= \pm 2 \%$
\end{tabular}




\subsection{Test rig operating procedure}

At the start of the experiment, a valve from the propane cylinder is opened, and then the micro-tubular SOFC, the WHR pump, and the environmental chamber are switched on. WRR pump and chamber temperature/humidity is then set. Valves to the dehumidifier are switched off and a by-pass loop is opened to allow the system to gain working temperature rapidly. For the first 30 minutes or so, the micro-SOFC does not produce electrical power because it needs to reach a temperature of $200-300^{\circ} \mathrm{C}$ to enable it to reform fuel into hydrogen. The system is allowed to operate in by-pass mode until the water outlet temperature reaches approximately $50^{\circ} \mathrm{C}$. In advance of the system reaching $50^{\circ} \mathrm{C}$, the fans and pumps in the dehumidifier rig are started and flows are set. Once the system temperature reaches $50^{\circ} \mathrm{C}$, the by-pass valves are shut and the valves to the regenerator are opened. Temperatures and humidity are recorded by a datalogger and voltage, current and volume flows and recorded until the completion of testing.

Once testing is complete, the micro-SOFC is switched off. It takes about 30 minutes for the microSOFC to shut down. The desiccant system is switched off, the valves to it shut and the by-pass valves opened. Once the micro-SOFC shuts down the water flow and propane gas are switched off.

\section{Results}

\subsection{Micro-tubular SOFC bench tests}

According to the manufacturer, the nominal power output of the micro-tubular SOFC was approximately $250 \mathrm{~W}$. Figure 4.1 shows the bench test results.

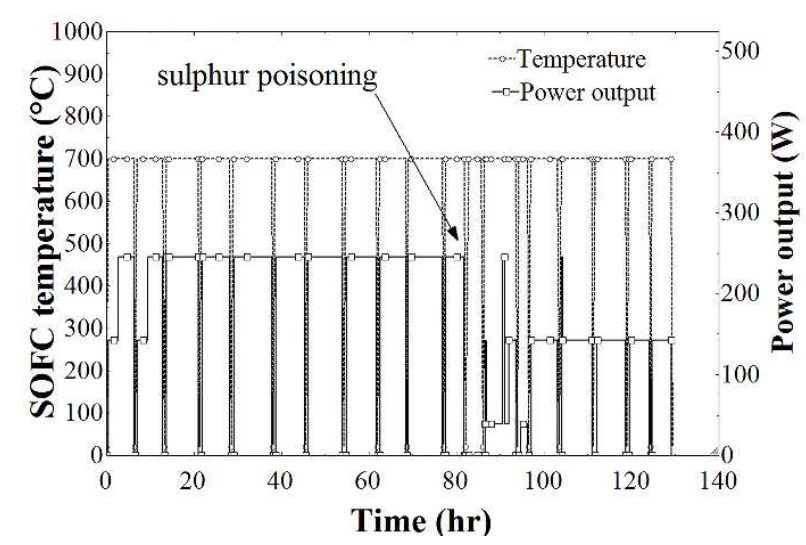

Figure 4.1. Variation in power output and temperature with time

The micro-tubular SOFC unit was tested for approximately 130 hours, including 19 thermal cycles from room temperature to operating temperature $\left(\sim 700^{\circ} \mathrm{C}\right)$, one forced stop and one severe sulfur poisoning event. High purity propane gas (99.5\%) was used for the first 8 cycles, or approximately 66 hours, and then BBQ propane gas was used from the $9^{\text {th }}$ thermal cycle until the end of testing. Prior to bench testing at UoB, the system had been running for 190 hours.

Figure 4.1 shows that the power output and temperature remained constant throughout the tests, with very little deviation or degradation. From the beginning of the test until the $11^{\text {th }}$ cycle, the power output was approximately $250 \mathrm{~W}$, whilst the SOFC temperature remained constant at approximately $700^{\circ} \mathrm{C}$.

The graph shows excellent start-up and stop characteristics, with very little degradation over the period. At approximately 80 hours of operation and after 11 cycles, the power output drops to zero. Power output then recovers slowly, until it reaches a maximum of approximately $140 \mathrm{~W}$. The reason that the power output drops and is below the original value is that sulphur poisoning occurs. A sulphur trap was installed in the system, but unfortunately it became full before a replacement could be installed. 
However, this shows that sulphur poisoning has not completely caused the failure of the fuel cell and that it can recover significant performance after such an event.

\subsection{Micro-SOFC CHP system component analysis}

Figure 4.2(a) presents typical micro-SOFC output and Figures 4.3 to 4.5 compare the performance of the tri-generation system at different regenerator solution flows of $3.21 / \mathrm{min}, 2.2 \mathrm{1} / \mathrm{min}$ and $1.2 \mathrm{l} / \mathrm{min}$, respectively. In Figure 4.2(a), during the first 26 minutes, gas burners generate heat to bring the microSOFC to its operating temperature. During this period, a parasitic load of approximately $35 \mathrm{~W}$ was observed as well as waste heat output. The flue gas temperature leaving the micro-SOFC and entering the RHX remained approximately constant at around $340^{\circ} \mathrm{C}$. During electrical power generation, the output was approximately constant at $150 \mathrm{~W}$. From the start of the test to approximately 130 minutes, the system was in by-pass mode and the heat recovered raised the temperature of the WHR system, therefore there was no external heat transfer. At this point the WHR outlet temperature reached approximately $52^{\circ} \mathrm{C}$, the valves to the regenerator were opened and the by-pass valves closed. As heat was transferred to the solution, the WHR inlet and outlet temperatures decreased. Even though the temperatures steadily decreased over time, regenerator heat transfer was approximately constant at $580 \mathrm{~W}$.

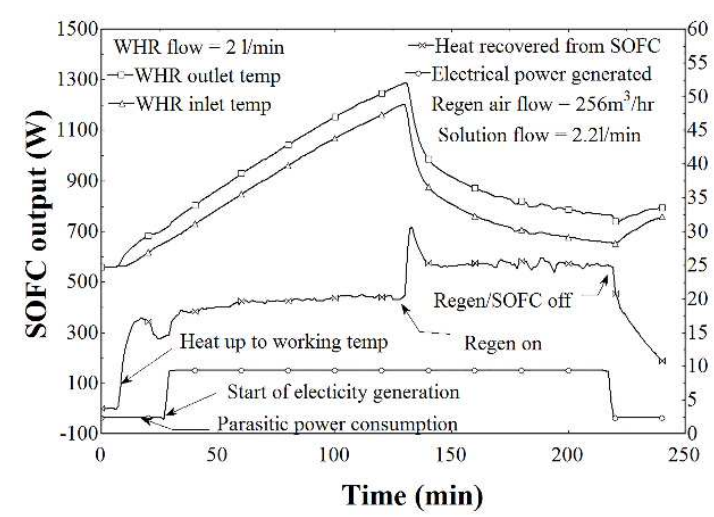

(a)

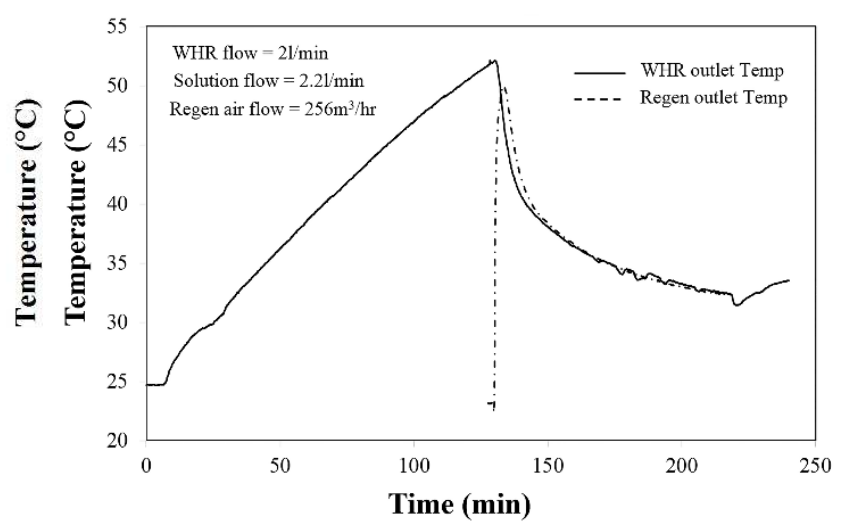

(b)

Figure 4.2. Variation in (a) SOFC output and temperature with time, at constant WHR, Regen solution and Regen air flows of $21 / \mathrm{min}, 2.21 / \mathrm{min}$ and $256 \mathrm{~m}^{3} / \mathrm{hr}$, respectively, (b) regeneration solution and WHR outlet temperature.

Figure 4.2(b) shows the temperature of the solution outlet and WHR outlet over time. There is a rapid increase in temperature of the regenerator solution as the WHR is introduced to the heat exchanger. There is a hysteresis effect as the plate heat exchanger absorbs the heat and retains the WHR temperature. This is passed on to the regenerator, which exceeds the WHR outlet temperature for a short period. Figure 4.2.b. shows that the heat has a very high effectiveness and transfers the heat with very little pinch temperature difference.

In figure 4.3, the regenerator heat absorbed increases rapidly following the opening of the valves and steadily decreases over time. The regenerator heat absorbed and the latent heat absorbed decrease over time. At 100 minutes, the regeneration heat recovery was approximately $500 \mathrm{~W}$ and the latent heat absorbed was approximately $200 \mathrm{~W}$. The solution inlet temperature at this point was $36.4^{\circ} \mathrm{C}$. 


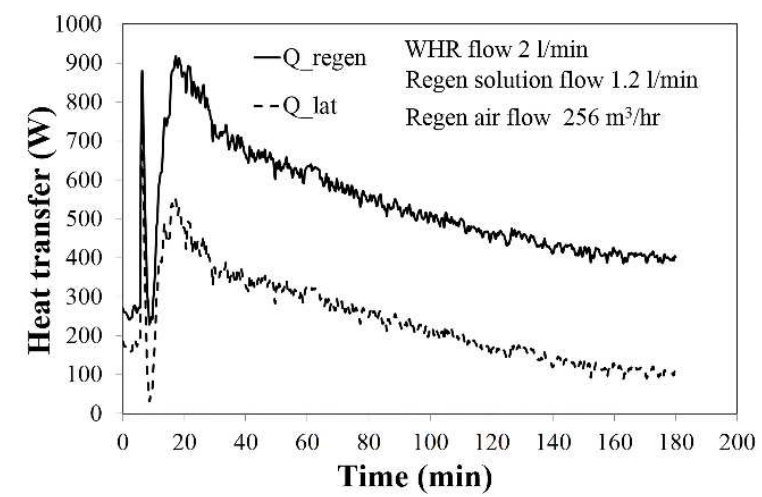

Figure 4.3. Variation in heat transfer with time, at constant WHR, Regen solution and Regen air flows of $21 / \mathrm{min}, 1.21 / \mathrm{min}$ and $256 \mathrm{~m}^{3} / \mathrm{hr}$, respectively (Case C).

Figure 4.4 shows results from tests carried out at a solution flow of $2.21 / \mathrm{min}$. In this case, regeneration continues and tends to a constant value of approximately 550W. At a solution flow of $2.2 \mathrm{l} / \mathrm{min}$, the regeneration heat recovery was approximately $600 \mathrm{~W}$ and the latent heat absorbed was around $400 \mathrm{~W}$ after 60 minutes. The solution inlet temperature was approximately $33.5^{\circ} \mathrm{C}$.

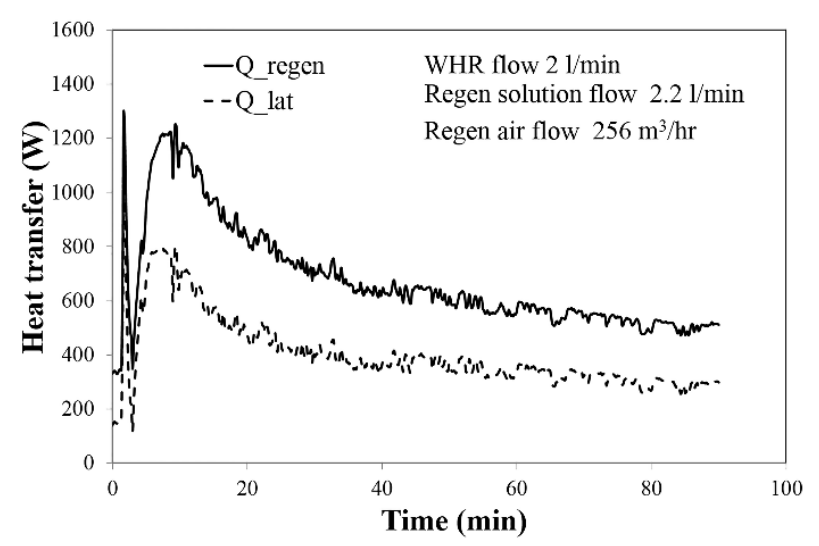

Figure 4.4. Variation in heat transfer with time, at constant WHR, Regen solution and Regen air flows of $21 / \mathrm{min}, 2.21 / \mathrm{min}$ and $256 \mathrm{~m}^{3} / \mathrm{hr}$, respectively (Case B).

Figure 4.5 shows the results of tests carried out at a solution flow of $3.21 / \mathrm{min}$. The latent heat absorbed by the regenerator increases rapidly on opening of the flow and then steadily decreases over time until regeneration ceases at approximately 120 minutes. Beyond this point the moisture is desorbed by the air and therefore the regenerator acts as a dehumidifier. The main reason that there is a reverse in sorption is that the solution inlet temperature decreases to a value of approximately $31^{\circ} \mathrm{C}$ after about 100 minutes. This reduces the solution vapour pressure, and therefore the pressure difference between the air and solution. 


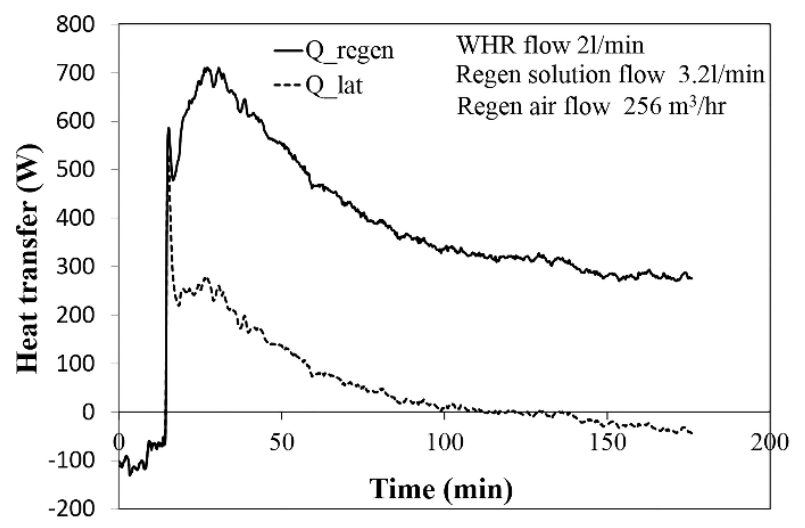

Figure 4.5. Variation in heat transfer with time, at constant WHR, Regen solution and Regen air flows of $21 / \mathrm{min}, 3.21 / \mathrm{min}$ and $256 \mathrm{~m}^{3} / \mathrm{hr}$, respectively (Case A).

The mass regenerated in the three cases was estimated from integration of the curves over an 80 minute period starting from peaks observed following start-up. The mass of water regenerated for Cases A, B and $\mathrm{C}$ was $211 \mathrm{~g}, 721 \mathrm{~g}$ and $596 \mathrm{~g}$, respectively. Over the 80 minute time period, the regeneration heat transfer was $0.67 \mathrm{kWh}, 0.87 \mathrm{kWh}$ and $0.85 \mathrm{kWh}$, respectively, whilst the latent heat transfer was $0.15 \mathrm{kWh}, 0.51 \mathrm{kWh}$ and $0.42 \mathrm{kWh}$, respectively. Therefore, Case B produced the highest mass regenerated and therefore was the most effective in converting the waste heat from the micro-SOFC into regeneration. For case B, the regeneration and latent heat transfer rates approximate a steady state after about 70 minutes, with average values of $516 \mathrm{~W}$ and $300 \mathrm{~W}$, respectively.

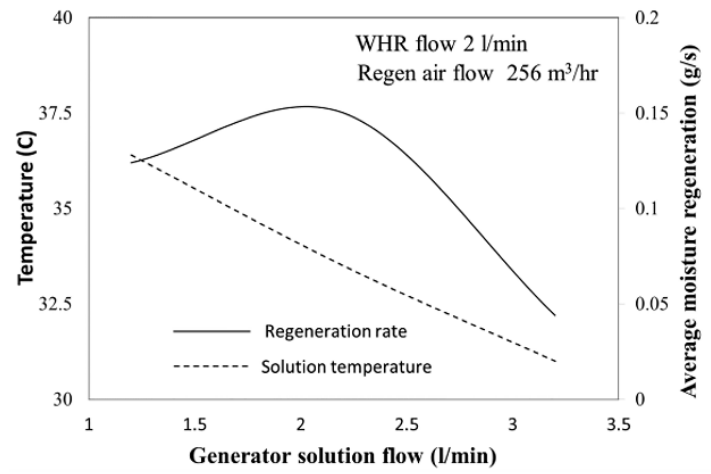

Figure 4.6. Variation in regenerator solution temperature and moisture removal rate with solution flow

Figure 4.6 shows how the temperature and solution flow effect average regeneration rates. As flow increases, from $1.11 / \mathrm{min}$ though $2.21 / \mathrm{min}$ and on the $3.21 / \mathrm{min}$, solution temperature decreases approximately linearly with flow. In contrast, average moisture regeneration rate increases, reaches a maximum and then decreases. At low solution flows, not all of the solution is in contact with the fibre membrane and so regeneration is less than optimum. The temperature is the highest because at low flows it has long contact time with the WHR flow across the plate heat exchanger. It was shown in Figure 4.2(b) that this exchanger has a very high effectiveness, and so the heat is easily transferred. At the peak regeneration rate, it was concluded that this was the flow that gave maximum coverage of the fibre membrane. At the highest solution flow, average mass regenerated is reduced. At a flow of $3.21 / \mathrm{min}$, the membrane is flooded with solution, contact time is reduced, and the temperature decreases further. 


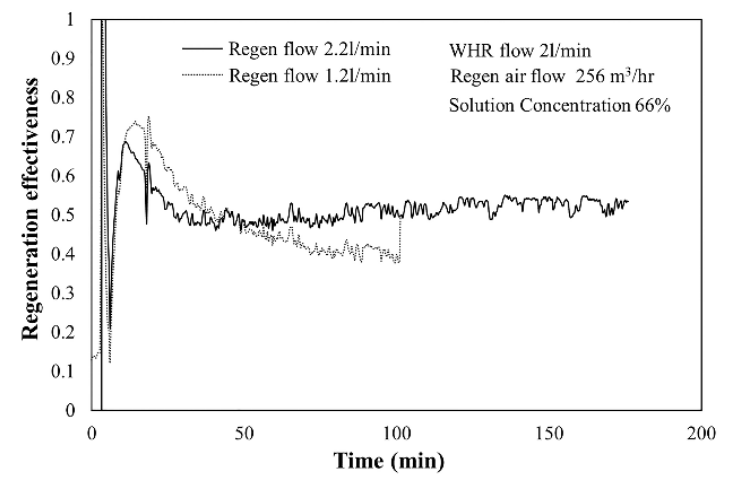

(a)

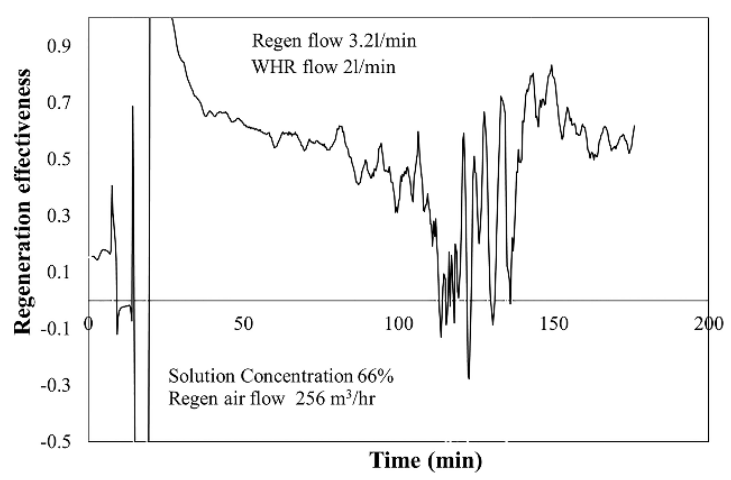

(b)

Figure 4.7. Variation in regeneration effectiveness with time for the three solution flows, (a) 1.2, 2.2 and (b) $3.21 / \mathrm{min}$.

Figure 4.7(a) shows how regeneration effectiveness changes with time for the solution flows, 1.2 and $2.2 \mathrm{l} / \mathrm{min}$. Regeneration effectiveness initially rises rapidly as the heat is suddenly applied with an opening of the valves to the solution exchanger. Effectiveness slowly decreases over time and reaches a steady state after a period as the solution temperature becomes approximately constant. At $1.21 / \mathrm{min}$, effectiveness reduces steadily until it reaches approximately 0.37 . The increase at 100 minutes is thought to be due to a small reduction in temperature from $31^{\circ} \mathrm{C}$ to $29.4^{\circ} \mathrm{C}$ at this point. There is then an increase to approximately 0.50 at around 100 minutes into the test. Effectiveness remains approximately $0.50 \pm 0.05$ for the remainder of the test. At $2.21 / \mathrm{min}$, effectiveness steadily decreases to about 0.46 at 20 minutes then slowly increases to $0.50 \pm 0.05$ for the remainder of the test. This increase is again due to a steady reduction in temperature over time.

Figure 4.7(b) shows the results for regeneration effectiveness over time for a solution flow of $3.21 / \mathrm{min}$. The reduction in effectiveness is continuous and reaches zero at approximately 112 minutes. The effectiveness oscillates around the zero mark for around 5 minutes and eventually starts to increase with positive values beyond 120 minutes. It was noted in discussion of figure 4.2 that latent heat transfer became negative beyond approximately 120 minutes. The point at which the regeneration effectiveness oscillates (110-120minutes) is where the absolute humidity in the supply air and the absolute humidity above the solution at the equilibrium temperature and concentration are equal. Beyond this point, absolute humidity difference between the solution and air drives moisture absorption. The reason that regeneration effectiveness increases to a positive value beyond 120 minutes is that both numerator and denominator become negative. (i.e. inlet absolute humidity is greater than outlet absolute humidity and inlet absolute humidity is greater than the absolute humidity above the solution at the equilibrium temperature and concentration).

The main reason for the decrease in desorber temperature over time was due to the desiccant unit operating in an environmental chamber with set temperature and relative humidity, creating a thermal sink for the system. Heat recovered from the recuperator was circulated to the desiccant unit and returned at temperatures close to the environmental chamber temperature. The temperature difference across the recuperator remained approximately constant, with the consequence that the outlet temperature from the recuperator decreased over time. The system was set up in this way to enable us to investigate the system directly integrated through the recuperator and desiccant unit plate HX and operating in a real conditions.

The results showing regeneration at relatively low liquid absorber temperatures $\left(33-36^{\circ} \mathrm{C}\right)$ was surprising, as we expected to require temperatures of above $45^{\circ} \mathrm{C}$ to obtain any moisture desorption. This demonstrates that liquid desiccants are able to desorb at relatively low pressure gradients between 
the liquid desiccant pressure and the pressure of water vapour above the surface, and could be effective in utilising waste heat and low temperature heat resources normally dismissed as unusable.

It was observed that even at relatively low absorber temperatures, regeneration (desorption) can be carried out. Not only does this provide instantaneous desorption, but the concentrated liquid that results from the process can be stored for use at other times. The storage of concentrated liquid solution is a form of coolth storage; one that can provide dehumidification and cooling from the difference between the vapour pressure differences between the solution and the water vapour in the air. As long as moist air is prevented from coming into contact with the solution, the concentration will not decrease over time, and therefore the coolth can be stored almost indefinitely. This is a valuable thermal storage resource that is underused, unappreciated and can be produced at relatively low temperatures $\left(40-60^{\circ} \mathrm{C}\right)$.

The average values of various parameters are shown in Table 4.1, together with the instantaneous performance results.

\begin{tabular}{lclll}
\hline \multicolumn{5}{l}{ Table 4.1. Instantaneous performance of the micro-tubular SOFC trigeneration system } \\
\hline Variable & \multicolumn{2}{l}{ value } & Variable & value \\
\hline Electrical output $W_{\mathrm{e}}$ & $150 \mathrm{~W}$ & Electrical efficiency & $\eta_{\text {elec }}$ & $10.7 \%$ \\
Dehumidification cooling $Q_{\text {cool }}$ & $527 \mathrm{~W}$ & Tri-gen efficiency & $\eta_{\text {tri }}$ & $50.0 \%$ \\
Parasitic power $W_{\text {e-out }}$ & $\sim 110 \mathrm{~W}$ & Latent efficiency & $\eta_{\text {regen }}$ & $28.6 \%$ \\
Fuel input $Q_{\text {fuel }}$ & $1288 \mathrm{~W}$ & COP $_{\text {tri }}$ & & 0.799 \\
Regeneration output & $Q_{\text {regen }}$ & $550 \mathrm{~W}$ & & \\
Latent regeneration & $Q_{\text {lat }}$ & $250 \mathrm{~W}$ & & \\
\hline
\end{tabular}

An electrical efficiency of $11 \%$ is very low compared to other SOFC systems, however, the microtubular SOFC is still at an early stage of development, and if issues such as electrical connections, efficient power extraction, manifold design and optimised fuel and oxygen flow regimes (Lawler et al, 2009) are addressed then more efficient systems will be available, with the advantages of good stopstart characteristics, the ability to withstand large thermal cycles and long term performance and durability. Tri-generation efficiency is $50 \%$, which shows that the integration of the desiccant dehumidification and cooling system with the fuel cell enhances its performance significantly. The heat recovered $(550 \mathrm{~W})$ could be used for any purpose, but we want to use it for regenerating moisture, therefore, the regeneration efficiency is just under $30 \%$. When we investigate the cooling side of the system, we find that the tri-generation COP is almost 0.8 . This represents the proportion of the cooling that can be achieved from the waste heat, taking into account the parasitic losses. This value is quite a good achievement at these low regeneration temperatures $\left(33-36^{\circ} \mathrm{C}\right)$.

The regeneration tests described above were carried out in regeneration mode only and so we propose to compare the regeneration performance reported here with dehumidification performance evaluations carried out in previous tests. Assuming that case B is the most suitable set-up for the system, we may use the results to evaluate performance over a given period of time. In previous publications, Elmer, $2015^{1}$ has reported the performance of the dehumidification unit and found that the maximum mass dehumidification rates obtainable were $0.2 \mathrm{~g} / \mathrm{s}$. All other parameters relevant to performance evaluation are given in Table 4.2. 


\begin{tabular}{llll}
\hline \multicolumn{4}{l}{ Table 4.2. Daily micro-SOFC trigeneration performance parameters } \\
\hline Variable & value & Variable & value \\
\hline$T_{\text {amb }}$ & $30^{\circ} \mathrm{C}$ & Dehumidification rate & $\sim 0.2 \mathrm{~g} / \mathrm{s}$ \\
$\mathrm{RH}_{\text {amb }}$ & $70 \%$ & Dehumidifier cooling & $\sim 527 \mathrm{~W}$ \\
Dehumidifier air flow & $256 \mathrm{~m}^{3} / \mathrm{hr}$ & Regeneration rate & $\sim 0.1 \mathrm{~g} / \mathrm{s}$ \\
Dehumidifier solution flow & $3.21 / \mathrm{min}$ & Regeneration input & $\sim 350 \mathrm{~W}$ \\
Evap air flow & $245 \mathrm{~m}^{3} / \mathrm{hr}$ & Latent regeneration & $\sim 250 \mathrm{~W}$ \\
Evap water flow & $11 / \mathrm{min}$ & Fuel input & $\sim 1288 \mathrm{~W}$ \\
\hline
\end{tabular}

The dehumidification and regeneration rates are not equal, so in order to operate the system, we could operate the regenerator at off-peak periods and operate the dehumidifier when demand for it is required. Assuming that dehumidification is required for 6 hours, then a mass balance shows that the regenerator could run for 12 hours, providing sufficient regeneration to satisfy the dehumidification demand.

Table 4.3 shows the durations of operation and energy transfers of various parts of the system.

\begin{tabular}{llll}
\hline \multicolumn{3}{l}{ Table 4.3. Daily micro-tubular SOFC trigeneration efficiency parameters } \\
\hline Variable & value & Variable & value \\
\hline Electrical output & $150 \mathrm{~W}$ & Regeneration duration & $12 \mathrm{~h}$ \\
Duration of SOFC & $18 \mathrm{~h}$ & Regeneration input & $6.6 \mathrm{kWh}$ \\
Electrical energy & $2.7 \mathrm{kWh}$ & Latent regeneration & $3 \mathrm{kWh}$ \\
Duration of Dehumidification & $6 \mathrm{~h}$ & Fuel energy input & $23.18 \mathrm{kWh}$ \\
Dehumidification cooling & $3.16 \mathrm{kWh}$ & $\eta_{\text {tri-daily }}$ & $36.9 \%$ \\
Parasitic power (pumps/fans, etc) & $\sim 110 \mathrm{~W}$ & $\eta_{\text {regen-daily }}$ & $22.7 \%$ \\
Parasitic energy duration & $18 \mathrm{~h}$ & $\mathrm{COP}_{\text {tri-daily }}$ & 0.368 \\
Parasitic energy consumption & $1.98 \mathrm{kWh}$ & & \\
\hline
\end{tabular}

Table 4.3 shows that daily tri-generation efficiency is approximately $37 \%$ and daily tri-generation COP is 0.368 . These values are lower than the instantaneous values because the fuel cell needs to operate for a longer period than the cooling cycle to regenerate enough moisture to match the amount absorbed in the dehumidifier. This shows that the addition of a dehumidification system increases the regeneration efficiency of the system from approximately $11 \%$ to $23 \%$, a doubling in efficiency. The tri-generation COP is low at 0.368 , because at the low regenerator temperatures $\left(33-36^{\circ} \mathrm{C}\right)$ we cannot match the dehumidification rates. If the heat recovered from the exhaust gases could be stored at a higher temperature using either water or a phase change material, then the rate of regeneration could be at least doubled.

\section{Conclusions}

This paper has described a micro-SOFC trigeneration system integrating a microtubular solid oxide fuel cell and an open cycle membrane separated dehumidification and cooling system. We have demonstrated regeneration of moisture from a liquid desiccant at relatively low temperatures $23-25 \mathrm{C}$, using heat recovered from the SOFC. The maximum moisture regeneration rates were in the region of 0.1-0.15 g/s, which equates to about 300-400W of latent heat absorbed. Electrical efficiency was low at around $11 \%$, but we have showed that the integration of the dehumidification unit more than doubled the efficiency to $23 \%$. The fuel cell we used was originally $250 \mathrm{~W}$ of electrical output, but sulphur poisoning reduced its performance. A unit with design specification output would achieve an electrical efficiency of $18 \%$ and an overall tri-generation efficiency of $30 \%$. 


\section{Acknowledgements}

The research leading to these results has received funding from the European Union's Seventh Framework Programme (FP7/2007-2013) for the Fuel Cells and Hydrogen Joint Technology Initiative under grant agreement No: 303454.

We would also like to thank Kevin Kendall of Adelan Ltd for providing the micro-tubular SOFC for use in our research and for his technical assistance and advice.

\section{References}

ASHRAE, 1997, ASHRAE Handbook: Fundamentals, Chapter 21, American Society of Heating, Refrigerating and Air-Conditioning Engineers, Atlanta, GA.

Boyd, J. (2008). IEEE Spectrum: Home Fuel Cells to Sell in Japan. Retrieved 27/04/2012, from http://spectrum.ieee.org/energy/renewables/home-fuel-cells-to-sell-in-japan.

Crabtree, G, W, Dresselhaus, M, S, (2008). The hydrogen fuel alternative, MRS Bulletin, 33, (April), 421-428.

Elmer, T, Worall, M, Wu, S, Riffat S, (2016). An experimental study of a novel integrated desiccant air conditioning system for building applications, Energy and Buildings, 111, 434-445.

Elmer, T, Worall, M, Wu, S, Riffat, S. B, (2015a). Fuel cell technology for domestic built environment applications: State of-the-art review: Renewable and Sustainable Energy Reviews, 42, 913-931.

Elmer, T, (2015b). A novel SOFC tri-generation system for building applications, PhD Thesis, University of Nottingham, UK.

Hawkes, A., Staffell, I, Brett, D, Brandon, N, (2009). Fuel cells for micro-combined heat and power generation. Energy \& Environmental Science 2(7): 729-744

Howe, K. S, Thompson, G, J Kendall, K, (2011). Micro-tubular solid oxide fuel cells and stacks, Journal of Power Sources, 196, 4, 1677-1686.

Kazempoor, P., Dorer, V, Weber, A, (2011). Modelling and evaluation of building integrated SOFC systems. International Journal of Hydrogen Energy 36(20): 13241-13249

Kozubal, W, Woods, J, Burch, J, Boranian, A, Merrigan, T. (2011). Desiccant Enhanced Evaporative Air-Conditioning (DEVap): Evaluation of a New Concept in Ultra Efficient Air Conditioning.

Liu, S, Zhao, X, Riffat, S, Yuan, Y, (2009). Theoretical and experimental investigations of a liquid desiccant filmed cellulose fibre heat and mass exchanger, International Journal of Energy Research, 33, 1076-1088.

Worall, M, Elmer, T, Wu, S, Riffat, S, (2013). Simulation of a desiccant dehumidifier for a low temperature solid oxide fuel cell (LT-SOFC) Tri-generation system In: Proceedings of the 12th International Conference on Sustainable Energy Technologies (SET 2013), Hong Kong. 


\section{Appendix A: Solution vapour pressure}

Calculation of equilibrium vapour pressure above the surface of a desiccant solution.

The mass fraction of the solution is given by;

$\mathrm{X}=100 \times C_{\text {sol }}$

Where $C_{\text {sol }}$ is the concentration (-).

The molar mass of water is;

$\mathrm{M}_{\mathrm{H} 2 \mathrm{O}}=18.01534 \mathrm{~kg} / \mathrm{k}-\mathrm{mol}$

The molar mass of potassium formate is;

$\mathrm{M}_{\mathrm{HCOOK}}=84.01534 \mathrm{~kg} / \mathrm{k}-\mathrm{mol}$

The mass fraction of water in solution is given by;

$\mathrm{X}_{\mathrm{H} 2 \mathrm{O}}=100-\mathrm{X}$

The mass fraction of the solution is given by;

$\mathrm{X}_{\mathrm{m}}=1 /\left(1+\left(\mathrm{M}_{\mathrm{H} 2 \mathrm{O}} \cdot \mathrm{X}\right) /\left(\mathrm{M}_{\mathrm{HCOOK}} \cdot \mathrm{X}_{\mathrm{H} 2 \mathrm{O}}\right)\right)$

$\gamma=\mathrm{A}(1-\mathrm{Z})^{2} \cdot(1+4.19 . \mathrm{Z} \cdot(\mathrm{Z}-2 / 3))$

Factors $\mathrm{A}, \mathrm{B}$ and $\mathrm{Z}$ are determined from;

$\mathrm{A}=-2.08-1336 / T$

$\mathrm{B}=-3.42-1039 / T$

Where $T$ is the absolute temperature $(\mathrm{K})$;

$\mathrm{Z}=\mathrm{A} \cdot \mathrm{X}_{\mathrm{m}} /\left(\mathrm{A} \cdot \mathrm{X}_{\mathrm{m}}+\mathrm{B}\left(1-\mathrm{X}_{\mathrm{m}}\right)\right)$

The saturation vapour pressure of water vapour can be found from;

$p_{\mathrm{v}_{\_} \mathrm{H} 2 \mathrm{O}}=73.649-(7258.2 / T)-7.3037 . \mathrm{LN}(T)+4.1653 \mathrm{e}-6 * T^{2}$

The vapour pressure above the potassium formate solution is a given by;

$p_{\mathrm{v}_{\_} \mathrm{sol}}=\mathrm{X}_{\mathrm{m}} * \operatorname{EXP}(\gamma) . \operatorname{EXP}\left(p_{\mathrm{v}_{-} \mathrm{H} 2 \mathrm{O}}\right)$

The equilibrium absolute humidity for use in Eq.5 is given by;

$\omega_{e q}=0.622 \times p_{\mathrm{v}_{-} \mathrm{sol}} /\left(P_{a t}-p_{\mathrm{v}_{-} \mathrm{sol}}\right)$

(kg vapour/kg dry air)

Where $P_{a t}$ is atmospheric pressure $(\mathrm{Pa})$. 